\title{
Relationship Between the Practices of Learning Organization and Teacher Leadership at Indigenous Primary Schools of Kuala Langat District, Selangor, Malaysia
}

\author{
Saraswathy Kullan*, Mahaliza Mansor \\ Sultan Idris Education University, Malaysia
}

Corresponding author: Saraswathy Kullan (e-mail: saraswathy_kullan@yahoo.com)

\begin{abstract}
The main focus of this study was to (1) identify the level of the practices of learning organization, (2) identify the level of teachers' leadership, and (3) determine the relationship between practices of learning organization and teacher leadership. The theoretical framework of both Watkins and Marsick (1999) and Katzenmeyer and Moller (2009) were modified to form the conceptual framework of the study. The data were collected through questionnaires distributed to 72 teachers which were randomly selected from six Indigenous Primary Schools of Kuala Langat District, Selangor. The study was a quantitative research. The data collected was analyzed using descriptive and inferential statistics using the SPSS IBM Version 23.0 software. The results showed that the practices of learning organization by teachers recorded a high level of mean value at 3.87 and at 4.05 for teacher leadership. There was a moderate, positive and significant relationship between practices of learning organization and teacher leadership $(r=0.699, p<0.01)$. This finding promotes practices of learning organization in schools which may lead to positive changes in teacher leadership. The implication of the study is the practices of learning organization should be practised at individuals, teams and organization levels in schools to improve the leadership skills of teachers through learning continuously.
\end{abstract}

Keywords: learning organization, teacher leadership

\section{INTRODUCTION}

Sustainable Development Goals (SDGs) in particular SDG 4 advises that quality education plays a role as an agent of change. Inclusive education, equality and lifelong learning opportunities can encourage changes in knowledge, skills, values and attitudes to empower current and future generations to meet the economic, social and environmental balance of life towards achieving education quality (UNESCO, 2018; MOE, 2018). The various policies and education plans that determine the quality of the education system in a country are great but these will not have any positive impact as long as the quality of teachers who serve as policy practitioners and the plan is not improved first. Teachers in schools need to learn to stimulate their intellectual development and also that of and their peers proactively to change the needs 
of the education world (Fullan \& Hargreaves, 2016). Therefore, teachers in school need to adopting the best practices of learning organizations to constantly renew knowledge and stay relevant (Watkins \& Marsick, 1999; Marsick \& Watkins, 2003).

Since teachers are the most valuable resource available in schools, the low-performing students need qualified teachers to help them improve their performance (OECD, 2016). Aspects of teacher leadership in schools should be given priority to improve the quality of education in schools. Although teacher leadership is often associated with student achievement, Katzenmeyer and Moller (2001; 2009) interpret teacher leadership from different angles. According to them, the roles of teachers are not only in the classroom but they can also be leaders outside the classroom by contributing to the surrounding community, especially other teachers; authoritatively influencing others to improve educational practices in schools; willing to accept the duties and responsibilities to achieve success for themselves as well as their colleagues, students and school.

\subsection{Problem Statement}

According to Japar \& Dzulkifli (2017) and Yusof, Vyapuri, Jalil, Mansor, \& Noor (2017, p.77) the level of teacher leadership among teachers in Malaysia is still at a moderate level. Meanwhile, previous studies on the practices of learning organization recorded the overall mean at a moderate level (Bikmoradi, Fardmal, Torabi, 2018, p. 442). Therefore, the relationship between teacher leadership and teacher learning in schools needs to be studied in depth to find the best solution for leadership problems among teachers (Wenner \& Campbell, 2017 , p. 18 \& 19).

\subsection{Research Objectives}

a. Identify the level of the practices of learning organization at Indigenous Primary Schools of Kuala Langat District, Selangor.

b. Identify the level of teacher leadership at Indigenous Primary Schools of Kuala Langat District, Selangor.

c. Identify the relationship between the practices of learning organization and teacher leadership at Indigenous Primary Schools of Kuala Langat District, Selangor. 


\subsection{Research Questions}

a. What is the level of the practices of learning organization at Indigenous Primary Schools of Kuala Langat District, Selangor?

b. What is the level of teacher leadership at Indigenous Primary Schools of Kuala Langat District, Selangor?

c. What is the relationship between the practices of learning organization and teacher leadership at SKA, Indigenous Primary Schools of Kuala Langat District, Selangor?

\subsection{Research Hypothesis}

a. Ho1= There is no significant relationship between the practices of learning organization and teacher leadership at Indigenous Primary Schools of Kuala Langat District, Selangor.

\subsection{Literature Review}

Learning organization is an organization learning continuously and being able to change according to environmental changes (Watkins \& Marsick, 1999). In the 21st century, new trends in technology, economics and politics have a huge impact on social life, workplace and even the way of human life, especially for the younger generation who will lead a more complex world. To face this situation, teachers must prepare themselves with a variety of relevant and up-to-date global skills to meet the needs of students (Fullan, Quinn, \& McEachen, 2018). Therefore, teachers in schools need to practising the habit of learning and always gaining new knowledge so that they are competent and competitive because excellence of students and schools also depends on the competence, skills, expertise and authority of its teachers. Thus, the application and practices of the concept of learning organization enables either individuals or groups or organizations to be able to learn and adapt knowledge randoin this challenging new millennium education system (Watkins \& Marsick, 1999).

According to Katzenmeyer and Moller (2009), teachers play a role as leaders inside and outside of the classroom at school. As the recognition of the importance and influence of teachers is an essential component in the development of schools and the education system (Campbell, Lieberman, Yashkina, Alexander \& Rodway, 2018; Harris, Jones \& Huffman, 2017), researchers have recently conducted a literature review on the aspects of teacher leadership (Supovitz, 2018; York-Bark \& Duke, 2004). Many advanced studies and critical synthesis of teacher leadership have been conducted by experts according to current 
educational context and needs (Harris \& Jones, 2019; Spillane \& Shirrell, 2017; Fairman \& Mackenzie, 2015).

Rashid and Mansor (2018) have conducted a study on the influence of learning organization on teacher leadership. A total of 370 secondary school teachers participated in this quantitative study. The Katzenmeyer and Moller (2009) questionnaires were adapted to measure teacher leadership, while the questionnaires developed by Watkins and Marsick (1994) were used to assess learning organization. The findings of the study show that learning organization consisting of individual, group and organizational learning have an influence on teacher leadership but only to a minimum level. This indicate that there are other factors that influence teacher leadership. Therefore, other elements that can enhance teacher leadership need to be identified and promote learning organization in schools to improve the quality of teachers.

Meanwhile, Mansor, Yunus, Yuet, Musa and Noor (2019) studies about the influence of learning organization practices on teacher leadership. The sample of this study consisted of 400 teachers from 50 secondary schools. Findings of the study show that individual learning has a strong influence on teacher leadership, followed by global learning. Since the practices of learning organization can influence teacher leadership, it is appropriate to produce teacher leaders who can contribute to quality education.

\subsection{Research Framework}

In this study practices of learning organization is the independent variable, with three dimensions; individual learning, group learning, and organizational learning (Watkins \& Marsick, 1999). Teacher leadership is taken as dependent variable of this study (Katzenmeyer $\&$ Moller, 2009). A research framework of this study is proposed as in figure 1.

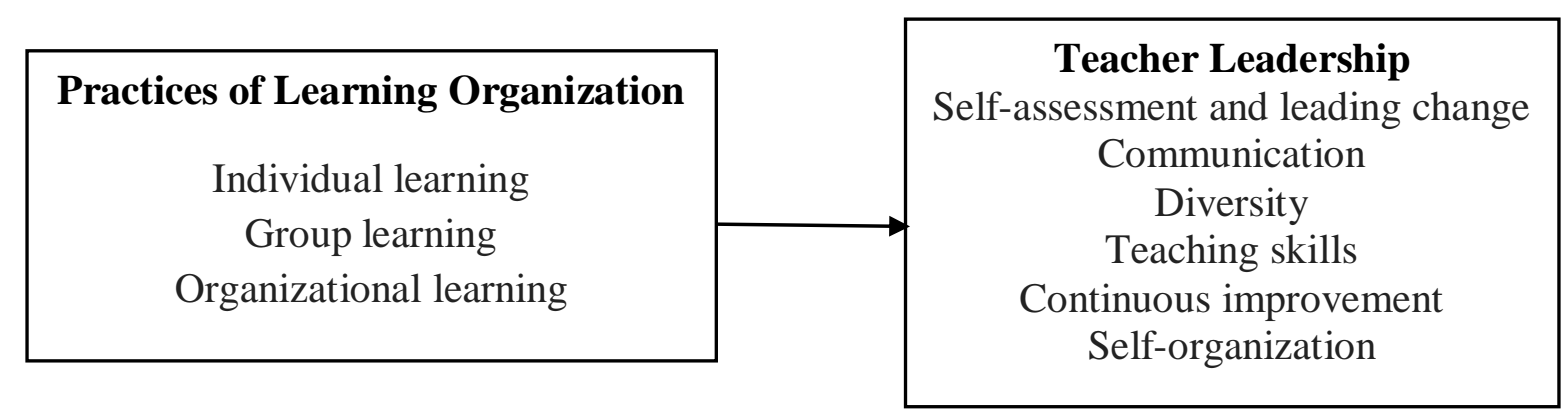

Figure 1. Research Model (Sources:Katzenmeyer \& Moller, 2009; Watkins \& Marsick, 1999) 


\section{METHOD}

This study is quantitative in nature using a descriptive correlation design because this design describes the correlation or existing relationship between practices of learning organization and teacher leadership. This study was conducted using cross-sectional survey design that used questionnaires for the purpose of data collection. Questionnaires include: Part A: Learning organization (Dimensions of the Learning Organization Questionnaire- DLOQ), Part BTeacher leadership (Teacher Leadership Self-Assessment -TLSA) and Part C-Demographics of respondents. The dimensions of DLOQ consist of (1) individual learning, (2) group learning and (3) organizational learning. Next, the dimensions of TLSA consist of (1) Self-assessment and leading change, (2) Communication, (3) Diversity, (4) Teaching skills, (5) Continuous improvement and (6) Self-organization. Finally, Section C examines the demographics of the respondents which includes 5 questions on gender, school category of school, academic level, teaching experience and age category.

The respondents of this study consisted 72 teachers from six indigenous primary school were selected using random sampling. The findings of the pilot study conducted showed that the Cronbach's Alpha value for the DLOQ instrument was .936 and for TLSA instruments was .964. Fraenkel, Wallen and Hyun (2012) stated that for study purposes, a reliability coefficient value of .70 or above is considered good. Thus, both study instruments were suitable for use because the coefficient value of these two instruments exceeded .70 . The mean descriptive statistics, standard deviations, frequency and percentage were used to determine the level of the practices of learning organization and teacher leadership. Meanwhile, frequency and percentage were used in analyzing the demographic information of the respondents. The researcher conducted the Pearson Correlation analysis to determine the strength of independent and dependent variable relationships in this study.

\section{RESULTS}

\subsection{Level of the practices of learning organization (DLOQ)}

RQ 1: What is the level of the practices of learning organization at Indigenous Primary Schools of Kuala Langat District, Selangor?

Table 1. Level of the practices of learning organization

\begin{tabular}{llccl}
\hline No & Learning Organization Practices & Mean & Standard deviation & Level \\
\hline 1. & Individual learning & 3.88 & 0.46 & High \\
2. & Group learning & 3.86 & 0.56 & High \\
3. & Organizational learning & 3.85 & 0.57 & High \\
\hline & Learning organization & 3.87 & 0.50 & High \\
\hline
\end{tabular}

Low=1.00-2.33; Medium=2.34-3.66; High=3.67-5.00 
The findings of this study showed that the three dimensions of the practices of learning organization were at a high level at six Indigenous Primary Schools of Kuala Langat District, Selangor (mean range between 3.85 to 3.88). The highest mean was for individual learning practices of $3.88(S . D=0.46)$. Next, the second highest mean of $3.86(S . D=0.56)$ is indicated by the level of group learning practice. Finally, the third highest mean was for organizational level learning practices with a mean of 3.85 (S.D = 0.57). Overall, the practices of learning organization were at a high level with a mean score of 3.87 (S. $\mathrm{D}=0.50)$.

\subsection{Level of teacher leadership (TLSA)}

RQ 2: What is the level of teacher leadership at Indigenous Primary Schools of Kuala Langat District, Selangor?

Table 2. Level of teacher leadership

\begin{tabular}{llccc}
\hline No & Teacher Leadership & $\begin{array}{c}\text { Mea } \\
\text { n }\end{array}$ & Standard deviation & Level \\
\hline 1. & Self-assessment and leading change & 4.09 & 0.42 & High \\
2. & Communication & 4.04 & 0.46 & High \\
3. & Diversity & 4.10 & 0.53 & High \\
4. & Teaching skills & 4.07 & 0.53 & High \\
5. & Continuous improvement & 3.95 & 0.51 & High \\
6. & Self-organization & 4.01 & 0.49 & High \\
\hline & Teacher leadership & 4.05 & 0.42 & High \\
\hline Low=1.00-2.33; Medium=2.34-3.66; High $=3.67-5.00$ & &
\end{tabular}

Low=1.00-2.33; Medium=2.34-3.66; High=3.67-5.00

The findings showed that all dimensions of teacher leadership were at a high level. The dimension with the highest mean was the diversity dimension (mean $=4.10, \mathrm{SP}=0.53$ ). This was followed by the dimensions of self-assessment and leading change (mean $=4.09$, SP $=$ 0.42 ), dimensions of teaching skills (mean $=4.07$, $\mathrm{SP}=0.53$ ), dimensions of communication $($ mean $=4.04, \mathrm{SP}=0.46)$, dimensions of self-organization $($ mean $=4.01, \mathrm{SP}=0.49)$ and dimensions of continuous improvement $($ mean $=3.95, \mathrm{SP}=0.51)$. Overall, the teacher leadership was at a high level with a mean score of 4.05 (S. D=0.42).

\subsection{Relationship between the practices of learning organization and teacher leadership}

RQ 3: What is the relationship between the practices of learning organization and teacher leadership at Indigenous Primary Schools of Kuala Langat District, Selangor?

Table 3. Relationship between the practices of learning organization and teacher leadership

\begin{tabular}{llll}
\hline & Teacher & Leadership & Relationship strength \\
\hline & $\boldsymbol{R}$ & Sig & \\
\cline { 2 - 3 } Practices of Learning Organization & .699 & .000 & Moderately strong \\
\hline$*$ Significant level $=0.01($-tailed) $\mathrm{p}<0.01$ & & &
\end{tabular}


The results of the analysis showed that there was a significant positive relationship at a moderately strong level between the practices of learning organization and teacher leadership $(\mathrm{r}=0.699, \mathrm{p}=0.000) \mathrm{p}<0.01$. Thus, the Ho1 hypothesis was rejected.

\section{DISCUSSION}

\subsection{Level of the practices of learning organization (DLOQ)}

RQ 1: What is the level of the practices of learning organization at Indigenous Primary Schools of Kuala Langat District, Selangor?

The findings of this study proved that all the practices of learning organization (individual learning, group learning and organizational learning) at six Indigenous Primary Schools of Kuala Langat District, Selangor were practised at a high level. This finding was in line with the study findings from (1) Rahim (2018) regarding the learning organization in secondary schools, (2) Ghani, Ishak, Siraj, Kenayathulla and Crow (2014) regarding the practices of learning organizational in an excellent school, and (3) Ishak, Ghani and Siraj (2014) regarding the leadership of learning organizations in High Performing Schools. On the other hand, Hussein, Omar, Noordin and Ishak (2016) who studied the culture of learning organizations at the Public Institution of Higher Education in Malaysia found that learning organizations were at a moderate level.

\subsection{Level of teacher leadership (TLSA)}

RQ 2: What is the level of teacher leadership at Indigenous Primary Schools of Kuala Langat District, Selangor?

The findings of this study found that the level of teacher leadership was high at all six Indigenous Primary Schools of Kuala Langat District, Selangor. Studies by (1) Yusof, Min, Jalil, Noor and Yusof (2018), (2) Harun, Sani, Sayuati and Abdullah (2018), and (3) Harun, Basri, Pehei and Asimiran (2016) were similar to the findings of this study where the level of teacher leadership in schools was at a high level. On the other hand, studies conducted by (Misdi, Sumintono, \& Abdullah, 2019) and (Yusof, Vyapuri, Jalil, Mansor, \& Noor, 2017) reported that the level of teacher leadership was still at a moderate level among teachers in Malaysia. 


\subsection{Relationship between the practices of learning organization and teacher leadership}

RQ 3: What is the relationship between the practices of learning organization and teacher leadership at Indigenous Primary Schools of Kuala Langat District, Selangor?

The practices of learning organization have been proven to influence teacher leadership in schools, especially in secondary schools (Mansor, Yunus, Yuet, Musa, \& Noor, 2019; Rashid \& Mansor, 2018). This statement can support the findings of this study which recorded a significant Pearson Correlation value of 0.699 at a moderately strong level between the practice of learning organization and teacher leadership. This showed that the overall practice of learning organization carried out in schools could increase the level of teacher leadership as well as bring out positive changes that promise the excellence of the school because teacher leadership is a process carried out by teachers individually or in groups within the organization to influence colleagues and principals to make improvements in the teaching, learning and development process in schools (York-Barr \& Duke, 2004). To achieve this objective, the development of teacher leadership should involve three stages, namely individual development, team development and also organizational development.

Overall, this study had filled the research gap on the level of practices of learning organization, teacher leadership and had proven that the relationship that existed between these two variables. Therefore, the practices of learning organization need to be implemented in schools at individual, group and organizational levels to bring progressive changes to teacher leadership because teachers with leadership values are known as highly skilled and qualified teachers. Such teachers are able to carry out the responsibilities in creating first class human capital as intended through Malaysia Education Development Plan 2013-2025 (MOE, 2013). Therefore, school as an organization must adopt the practices of learning organization in order to improve student learning and academic achievement, teacher professionalism and school reform.

\section{CONCLUSION}

The results of the study showed that the practices of learning organization in schools were important variables in determining the level of teacher leadership in schools. The results of this study which showed a moderately strong relationship between the practices of learning organization and teacher leadership should be given serious attention because scholars have confirmed the importance of the practices of learning organization in improving the level of teacher leadership in schools. 
The findings of this study would contribute towards two main implications. First, from a theoretical aspect this study would contribute to the development of literature on the practices of learning organization and teacher leadership, especially in primary schools. Secondly, in terms of practices, school head teachers need to implement the practices of learning organization according to the context of their respective schools in order to achieve (1) human capital development, (2) enhance leadership among teachers, (3) uphold teachers professionalism, (4) ensure the improvement of student achievement, and (5) improve the effectiveness of schools especially indigenous primary schools.

Since this study focused on only six indigenous primary schools, therefore this study could be replicated and conducted by using a larger sample by future researchers to generalize its findings. In addition, a positive and significant correlation at a moderately strong level between the practices of learning organization and teacher leadership provide an indicator that there may be other variables that can further strengthen the relationship between these two variables. Thus, this study could also be expanded by studying its relationship with the head teacher leadership in schools. In terms of methodology, (1) Structural Equation Modeling (SEM) analysis can be applied to ensure validity and reliability of the data, and (2) adopting the mixed method approach to enable the future studies to have a higher academic value.

Overall, this study was expected to give awareness to teachers to identify opportunities to do learning individually, in groups and also together with members of the organization to help teachers find out their abilities through teacher leadership which improve the quality of teacher professionalism.

\section{REFERENCES}

Bikmoradi, A., Fardmal, J., \& Torabi, Y. (2018). Correlation of Learning Organization with Organizational Commitment and Organizational Effectiveness of Educational and Therapeutic Centers of Hamadan University of Medical Sciences in Iran. Amazonia Investigate, 7 (13), 436-448. doi.org/10.29042/2018-3539-3547

Campbell, C., Lieberman, A., Yashkina, A., Alexander, S., \& Rodway, J. (2018). Teacher learning and leadership program: Research Report 2017-18. Toronto, Canada: Ontario Teachers' Federation.

Fairman, J. C., \& Mackenzie, S. V. (2015). How teacher leaders influence others and understand their leadership understand their leadership. International Journal of Leadership in Education, 18 (1), 61-87. doi.org/10.1080/13603124.2014.904002

Fraenkel, J. R., Wallen, N. E., \& Hyun, H. (2012). How to design evaluate research in education. New York: McGraw-Hill.

Fullan, M., \& Hargreaves, A. (2016). Bringing the profession back in: Call in action. Oxford, $\mathrm{OH}$ : Learning Forward.

Fullan, M., Quinn, J., \& McEachen, J. (2018). Deep learning: Engage the world, change the world. Thousand Oaks, CA: Corwin Press. 
Ghani, M. F. A., Ishak, R., Siraj, S., Kenayathulla, H.B., \& Crow, G. M. (2014). Keberkesanan Amalan Organisasi Pembelajaran di Sebuah Sekolah Cemerlang di Kuala Terengganu, Terengganu: Satu Kajian Awal. Jurnal Kurikulum \& Pengajaran Asia Pasifik, 2 (3), 22-42.

Harris, A., \& Jones, M. (2019). Teacher leadership and educational change. School Leadership \& Management, 39 (2), 123-126. doi.org/10.1080/13632434.2019.1574964

Harris, A., Jones, M., \& Huffman, J. (2017). Teachers leading educational reform: The power of Professional learning communities. Routledge, London.

Harun, A., Basri, R., Pehei, Z. A. L., \& Asimiran, S. (2016). Amalan kepimpinan guru di sekolah menengah zon timur semenanjung Malaysia. Jurnal Kepimpinan Pendidikan, 3 (4), 1-24. Retrieved from http://e-journal.um.edu.my/publish/JuPiDi/

Harun, A., Sani, A. G., Sayuati, I. S., \& Abdullah, K. (2018). Kesediaan Amalan Kepimpinan Guru di Sebuah Sekolah Rendah di Bawah Program Transformasi Sekolah 2025 (TS25), Zon Sabah. Jurnal Pengurusan dan Kepimpinan Pendidikan, 32 (1), 1-24. Retrieved from http://www.iab.edu.my.

Hussein, N., Omar, S., Noordin, F., \& Ishak, N. A. (2016). Learning Organization Culture, Organizational Performance and Organizational Innovativeness in a Public Institution of Higher Education in Malaysia: A Preliminary Study. Procedia Economics and Finance, 37 (16), 512-519. doi.org/10.1016/s2212-5671(16)30159-9

Ishak, R., Ghani, M. F. A., \& Siraj, S. (2014). Amalan Kepimpinan Organisasi Pembelajaran di Sekolah Berprestasi Tinggi Malaysia. Jurnal Kepimpinan Pendidikan, 1 (2). Retrieved from http://e-journal.um.edu.my/publish/JuPiDi/

Japar, S. N. H, \& Dzulkifli, D. N. A. K. (2017). Amalan kepimpinan guru terhadap pencapaian akademik pelajar di sekolah rendah ugama (SSSRU), Brunei Darussalam. In Prosiding Seminar Kebangsaan Majlis Dekan Pendidikan Universiti Awam 2017 (p.72).

Katzenmeyer, M., \& Moller, G. (2001). Awakening the Sleeping Giant: Leadership Development for Teachers ( $2^{\text {nd }}$ Edition). Thousand Oaks, California: Corwin Press Inc.

Katzenmeyer, M., \& Moller, G. (2009). Awakening the Sleeping Giant: Leadership Development for Teachers ( $3^{\text {rd }}$ Edition). Thousand Oaks, California: Corwin Press Inc.

Mansor, M., Yunus, J. N., Yuet, F. K. C., Musa, K., \& Noor, M. A. M. (2019). The Influence of Learning Organization Practices toward Teacher Leadership among Secondary School Teachers in State of Perak. International Journal of Academic Research in Progressive Education and Development, 8 (4), 91-102. doi.org/10.6007/IJARPED/v8-i4/6438

Marsick, V. J., \& Watkins, K. E. (2003). Demonstrating the value of a Organizational Learning Culture. Advances in Developing Human Resources, 5 (2), 132-151. doi.org/10.1177/1523422303251341

Ministry of Education. (2018). Laporan Tahunan PPPM 2017. Putrajaya: Kementerian Pelajaran Malaysia.

Ministry of Education. (2013). Pelan Pembangunan Pendidikan Malaysia 2013-2025 (Pendidikan Prasekolah hingga Lepas Menengah). Putrajaya: Kementerian Pelajaran Malaysia.

Misdi, N., Sumintono, B., \& Abdullah, Z. (2019). Kepemimpinan Guru Kolej Mara: Satu Kajian Kes. Jurnal Kepimpinan Pendidikan, 6 (3), 46-63.

OECD. (2016). School Leadership for Learning: Insights from TALIS 2013, TALIS. OECD Publishing, Paris. dx.doi.org/10.1787/9789264258341

Rahim, N. A. (2018). Pengaruh kepimpinan transformasi dan budaya sekolah terhadap organisasi pembelajaran sekolah menengah IMTIAZ di Malaysia. Jurnal Ilmi, 8, 6489. 
Rashid, R. A., \& Mansor, M. (2018). The Influence of Organizational Learning on Teacher Leadership. International Journal of Academic Research in Business and Social Sciences, 8 (4), 1255-1267. doi.org/10.6007/ijarbss/v8-i4/4236

Spillane, J. P., \& Shirrell, M. (2017). Breaking Up Isn't Hard to Do: Exploring the Dissolution of Teachers' and School Leaders' Work-Related Ties. Educational Administration Quarterly, 53(4), 616-648. doi.org/10.1177/0013161X17696557

Supovitz, J. A. (2018). Teacher leaders' work with peers in a Quasi-formal teacher leadership model leadership model. School Leadership \& Management, 38 (1), 53-79. doi.org/10.1080/13632434.2017.1389718

United Nations Educational, Scientific and Cultural Organization. (2018). Issues and trends in Education for Sustainable Development. Paris: France.

Watkins, K., \& Marsick, V. J. (1993). Sculpting the Learning Organization. San Francisco, Calif: Jossey-Bass.

Watkins, K., \& Marsick, V. J. (1996). In Action: Creating the Learning Organization. Alexandria, VA: American Society for Training and Development.

Watkins, K., \& Marsick, V. J. (1999). Facilitating Learning Organizations: Making Learning Count. Hampshire, England: Gower Publishing Limited.

Wenner, J. A., \& Campbell, T. (2017). The Theoretical and Empirical Basis of Teacher Leadership: A Review of the Literature. Review of Educational Research, 87 (1), 134171. doi.org/10.3102/0034654316653478

York-Barr, J., \& Duke, K. (2004). What Do We Know About Teacher Leadership? Findings from Two Decades of Scholarship. Review of Educational Research. 74 (3), 255-316. doi.org/10.3102/00346543074003255

Yusof, H., Min, Z. M., Jalil, N. A., Noor, M. A. M., \& Yusof, R. (2018). Teacher Leadership and Its Relationship with Students' Academic Achievement. International Journal of Academic Research in Business \& Social Sciences, 7 (1), 1551-1562. doi.org/10.6007/IJARBSS/v8-i9/4866

Yusof, H., Vyapuri, L., Jalil, N. A., Mansor, M., \& Noor, M. A. M. (2017). The Factors Affecting Teacher Leadership in Malaysian Primary Schools. International Journal of Academic Research in Business and Social Science, 7 (6), 620-631. doi.org/10.6007/IJARBSS/v7-i6/3025 